\title{
EXCESSIVE ORAL INTAKE CAFFEINE ALTERED CEREBRAL CORTEX HISTOARCHITECTURE AND CELL MORPHOLOGIES IN ADULT MICE
}

\author{
${ }^{*}$ Olatunji Sunday Yinka ${ }^{1}$ Owolabi Joshua Oladele ${ }^{1}$ and Olanrewaju Afees John ${ }^{1}$ \\ ${ }^{1}$ Department of Anatomy, Ben Carson [Snr.] School of Medicine, Babcock University, \\ Nigeria \\ *Corresponding author: Olatunji S Y, Department of Anatomy, Babcock University, Ogun \\ State, Nigeria. Tel: +2348069019522, E-mail: olatunjis@babcock.edu.ng, \\ adajosunday@yahoo.com
}

\begin{abstract}
Caffeine is commonly consumed in an effort to enhance speed in performance and wakefulness. However, little is known about the deleterious effects it can produce on the brain, this study aimed at determining the extents of effects and damage that can be caused by excessive consumption of caffeine on the cerebral cortex of mice models with a view to examining caffeine effects on cerebral cortex histoarchitecture and cell morphologies. Twenty adult mice were used for this study. They were randomly divided into 4 groups of 5 animals each. Control rats were administered normal saline, experimental groups received caffeine through oral cannula at 10,50 and $120 \mathrm{mg} / \mathrm{kg}$ body weight for 28 days to determine effects of graded doses of caffeine administration. The dosage of the caffeine selection was based on previously published work. The result indicates that at low and medium doses of caffeine administration, features of prominent eosinophilic cytoplasm with or without shrunken nuclei was observed in plates $1 \mathrm{~B}, 1 \mathrm{C}$, and $3 \mathrm{~B}, 3 \mathrm{C}$. And at high dose, features of degenerating neurons such as pyknotic nuclei and sparse neuronal population were observed in plates 2D and 3D when compared to the normal appearance of the neurons and the glial cells. In conclusion, low and medium doses of caffeine induced mild changes in cortical neuron morphology and at higher dose of caffeine administration, neurodegenerative changes were observed in cerebral histoarchitecture. This shows that at high dose, caffeine consumption can produce detrimental effects on brain structure as well as function in adult mice models.
\end{abstract}

Key Words: Caffeine, histoarchitecture, neuropil, cortical neurons

\section{INTRODUCTION}

Caffeine is one of the stimulants of the nervous system (NS). It is the world most widely consumed psychoactive drug which is legal and unregulated unlike many other psychoactive substances (Nehlig et al., 1992). Caffeine is a natural ingredient found in the leaves, seeds or fruit of a number of plants, such as coffee, tea, cocoa and kola; it is manufactured and used as a food additive in some carbonated drinks, and ingredient in certain drug products, such as cold and headache remedies (Bolton, 1981). The use of caffeine has been reported to reduce physical fatigue, treat drowsiness, increase wakefulness, improve thought-processing and better general body coordination. After oral ingestion of caffeine, mostly in the form of coffee or tea, about $99 \%$ of it is absorbed from the gastrointestinal tract into the bloodstream and it diffuses throughout the entire body, passes all biological membranes, including the bloodbrain barrier and the placental barrier (Snel et al., 2004). The metabolism and toxicity of caffeine are viewed to be dose dependent, and

Submitted $13^{\text {th }}$ September 2016, revised on $6^{\text {th }}$ January 2017. Published online $12^{\text {th }}$ January 2017 . To cite: Olatunji SY, Owolabi JO, Olanrewaju AJ. Excessive Caffeine Consumption Altered Cerebral Cortex Histoarchitecture and Cell Morphologies...856 - 861 . 
it has been implicated in neuronal disorder (Julien, 1996). The central nervous system stimulatory action of caffeine elevates mood and this accounts for much of the popularity that coffee and tea have as morning wake-up beverages in some homes. Caffeine acts by blocking the inhibition of adenosine in the brain cells, adenosine is an inhibitory neurotransmitter, synthesized from AMP by the action of s-nucleotidase, which acts to result in behavioural sedation, regulation of oxygen delivery to cells, dilation of cerebral and coronary blood vessels (Eteng et al., 1997). Caffeine and other methylxanthines occupy adenosine receptors and then block the action of the neurotransmitter. Adenosine receptors are linked with interplay of release, reuptake, metabolism and excretion of neurotransmitters (Obochi et al., 2010, Eteng et al., 1997). The cerebral cortex is a part of the brain that is situated in the anterior and middle cranial fossae and is one of the most important areas in the brain. This brain part is responsible for executive functions, which include mediating conflicting thoughts, making choices, predicting future events, and governing social and emotional control (Golgman, 1999). There have been many studies over the years dealing with caffeine and human health especially its effect on the brain. This study has looked at the potential adverse effects of caffeine on cortical neurones histoarchitecture and cell morphologies in adult mice model .

\section{MATERIALS AND METHODS}

\section{Animal Care and Drug administration}

A total number of 20 adult mice with an average weight of $20 \mathrm{~g}$ were obtained from the animal house of Babcock University, Ogun State. The mice were randomly divided into groups of four of five animals each (groups $A$, $B, C$ and D). The animals were housed in clean, well ventilated plastic cages at room temperature, under natural light and dark cycles. They were left to acclimatize for 8 days and afterwards used for the experiment. Care and treatment of animals were performed accordingly. Experimental groups received anhydrous caffeine dissolved in distilled water and was administered through oral cannula at

\begin{tabular}{|l|l|l|}
\hline Grouping & Animals & Dosage \\
\hline Group A & 5 & Control \\
\hline Group B & 5 & $10 \mathrm{mg} / \mathrm{kg}$ body weight \\
\hline Group C & 5 & $50 \mathrm{mg} / \mathrm{kg}$ body weight \\
\hline Group D & 5 & $\begin{array}{l}120 \mathrm{mg} / \mathrm{kg} \text { body } \\
\text { weight }\end{array}$ \\
\hline
\end{tabular}

10,50 and $120 \mathrm{mg} / \mathrm{kg}$ body weight. The administration was done at 8:00 am each day for 28 days to determine effects of graded doses of caffeine administration. The oral cannula was produced from the Physiology Department University of Ibadan, Nigeria and pure caffeine was obtained from Sigma-Aldrich Co. LLC $^{\circledR}$. The regimen was designed to model moderate, high and excessive consumption. Control animals were administered normal saline as placebo.

\section{Animal Treatment}

Table 1: Distribution of the experimental animals into groups, $20 \mathrm{~g}$ adult mice 5 groups of 4 rats each $(A, B, C, D)$.

\begin{tabular}{l|l|}
\hline $\begin{array}{l}\text { Description } \\
\text { animals receive a placebo } \\
\text { of distilled water }\end{array}$ & Rationale \\
\hline $\begin{array}{l}\text { Lower caffeine dosage } \\
\text { was administered to the } \\
\text { animals in this group }\end{array}$ & $\begin{array}{l}\text { Lower dose } \\
\text { treatment }\end{array}$ \\
\hline $\begin{array}{l}\text { Medium caffeine dosage } \\
\text { was administered to the } \\
\text { animals in this group }\end{array}$ & $\begin{array}{l}\text { Medium dose } \\
\text { treatment }\end{array}$ \\
$\begin{array}{l}\text { High caffeine dosage was } \\
\text { administered to the } \\
\text { animals in this group }\end{array}$ & $\begin{array}{l}\text { High dose } \\
\text { treatment }\end{array}$ \\
\hline
\end{tabular}




\section{Mode of Sacrifice}

Animals were given standard laboratory rat chow and water ad libitum. All animals were handled in accordance with the guidelines for animal research as detailed in the Guidelines for the Care and Use of Laboratory Animals (National Academy of Sciences and National Institutes of Health, 2011).

\section{Histological studies}

Following administration, mice were euthanized and the brain specimens were fixed in
$10 \%$ formalin. After fixation, specimens were dehydrated in an ascending series of alcohol, cleared in two changes of xylene and embedded in molten paraffin. Sections of 5 microns thickness were cut using rotary microtome and mounted on clean slides. For histological examination, sections were stained with hematoxylin and eosin (H\&E) methods for general histological demonstration;

\section{RESULTS}

The photomicrograph of the control group (A1, and $A 2$ ) shows well demonstrated neurons and neuroglia as compared to the treated groups (B 1\&2, C $1 \& 2$ and D 1\&2). Also, at low and medium doses of caffeine administration, features of prominent eosinophilic cytoplasm with or without shrunken nuclei were observed in Figures B1, C1, B2 and C2. And at high dose as shown in Figures D1 and D2, features of degenerating neurons in the cortical neurons such as pyknotic nuclei, and neuronal swelling were observed when compared to the normal appearance of the neurons and the glial cells in the control group. In addition, sparse neuronal population was observed in plates D1 and D2;
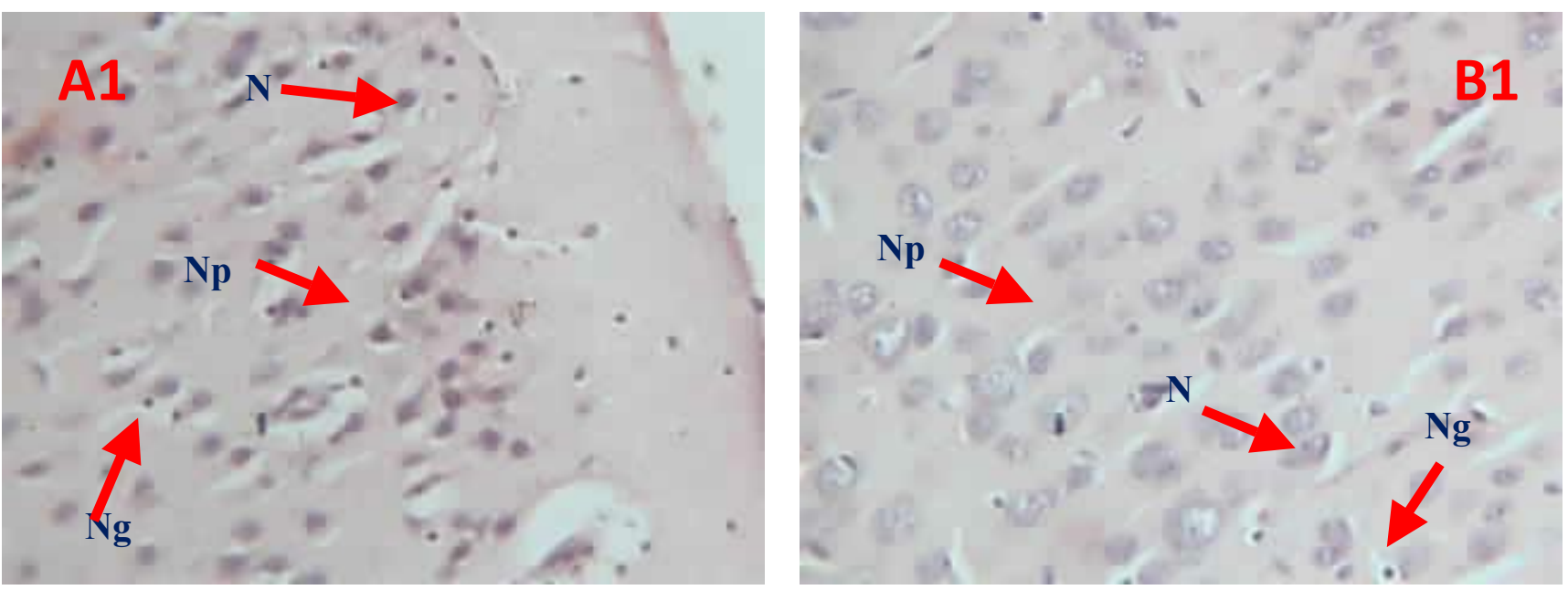
Anatomy Journal of Africa. 2017. Vol 6 (1): $856-861$.
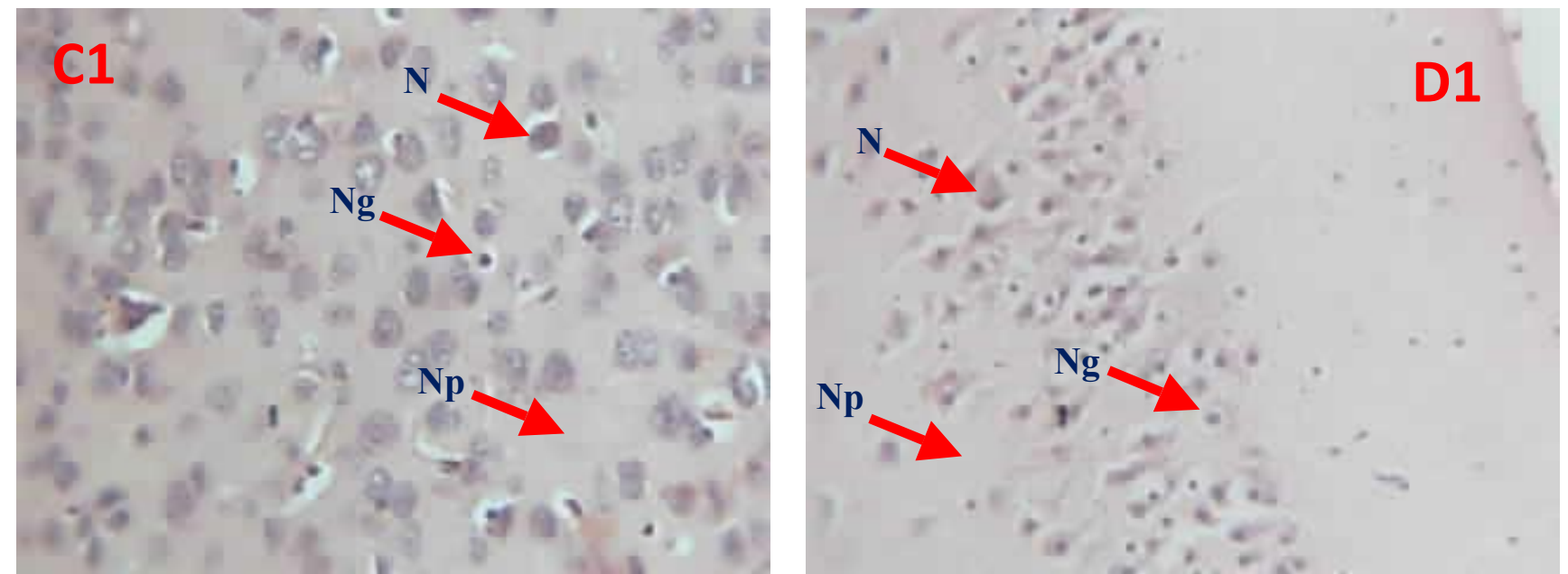

Figure 1: Photomicrograph sections of the cerebral cortex.A (Control), B (low dose $10 \mathrm{mg} / \mathrm{kg} \mathrm{bw),} \mathrm{C} \mathrm{(medium} \mathrm{dose} 50 \mathrm{mg} / \mathrm{kg}$ bw), D (high dose $120 \mathrm{mg} / \mathrm{kg}$ bw), N neuron, $\mathrm{Ng}$ - neuroglia, $\mathrm{Np}$ - neuropil H\&E X640.
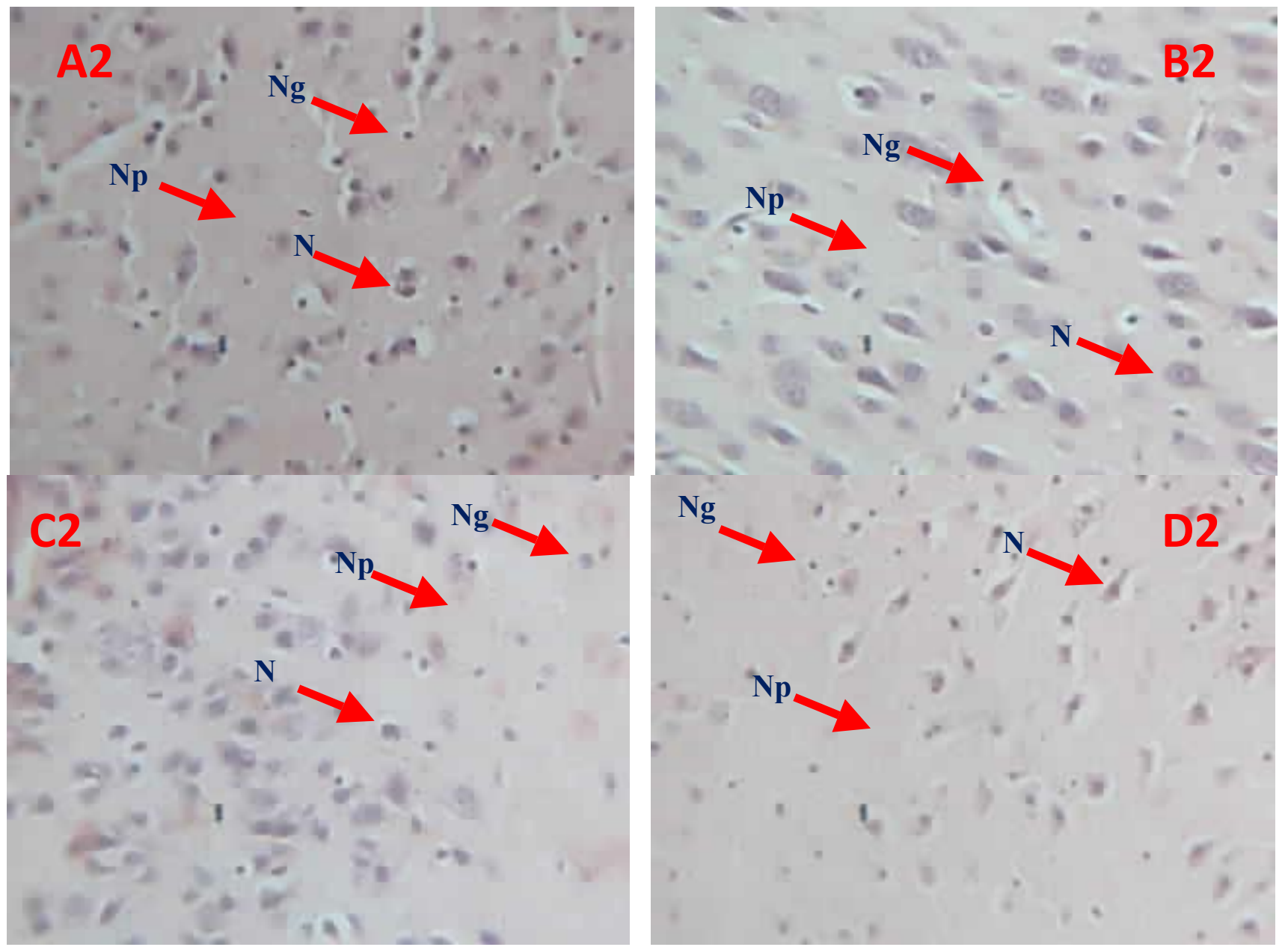

Figure 2: Photomicrograph sections of the cerebral cortex. A (Control), B (low dose $10 \mathrm{mg} / \mathrm{kg} \mathrm{bw}$ ), C (medium dose 50 $\mathrm{mg} / \mathrm{kg} \mathrm{bw}$ ), D (high dose $120 \mathrm{mg} / \mathrm{kg}$ bw), $\mathrm{N}$ neuron, Ng- neuroglia, Np- neuropil H\&E X640. 


\section{DISCUSSION}

This study investigated the effects of graded doses of caffeine in cortical neurons histoarchitecture and cell morphologies in the female mice models with a view to specially examining the extents of effects and damaged caused by excessive consumption of caffeine on the cerebral cortex. The result of the present study indicates that at low and medium doses of caffeine administration, features of prominent eosinophilic cytoplasm with or without shrunken nuclei these were observed in plates B1, C1, B2 and C2. And at high dose as shown in plates D1 and D2, features of degenerating neurons in the cortical neurons such as pyknotic nuclei, and neuronal swelling were observed when compared to the normal appearance of the neurons and the glial cells in the control group.

The current findings may not be unconnected with the findings of Angelucci et al (1999), who reported that caffeine has dual effect by causing memory improvement at lower doses and memory impairment at higher doses of caffeine administration in animal models. And also with the findings of Fatma et al (2015), who reported that caffeine intake in a dose of $1.5 \mathrm{mg} /$ day may reverse cognitive impairment and decrease brain $A \beta$ levels in aged mice and the response to treatment was in a dose dependent manner. The use of caffeine has been linked with specific disorders such as anxiety disorders, sleep disorders and eating disorders, and there is a possible association with schizophrenia. Surprisingly, there are no sufficient reports linking caffeine use with mania or hypomania (Winston, 2005) and its consumption may be higher in psychiatric patients than in the population as a whole (Greden, 1978, Scott, 1989).

Furthermore, sparse neuronal population was observed in plates D1 and D2; this can be attributed to high dose of caffeine administration in group $D$ which resulted in decrease in cell population, vacuolations and pyknotic changes. Higher doses of caffeine have previously been reported to produce selective degeneration in the brain (Fatma et al., 2015), this may be due to interference of excitoneurotoxic properties of caffeine. It has been reported by Martins et al.,(1978) that caffeine as one of the major ingredients of energy drink has been indicated in the process of cellular necrosis which involves disruption of the membranes structural and functional integrity. There is the need to further investigate the mechanism by which caffeinated drinks induced neuronal degeneration in the cortical neurons. Extensive cell death in the central nervous system is present in all neurodegenerative diseases (Waters, 1994) and the type of nerve cell loss and the particular part of the brain affected dictate the symptoms associated with an individual disease (Waters, 1994). In this study, high caffeine administration may have acted as toxin to the cells of the cerebral cortex. Caffeine exerts stimulatory effects by blocking the inhibitory action of adenosine at its binding sites; with subsequent increases in the levels in some brain regions of several neurotransmitters, including adrenaline, noradrenaline, tryptophan and dopamine (Schosberg, 1984, Schuckit, 2000, Dager et al., 1999)

In conclusion, low and medium dose of caffeine induced mild change in cortical neuron morphology and higher dose of caffeine consumption can produce detrimental effects on brain structure as well as function. It can be deduced from the present study that prolonged consumption of caffeine at a very high dose can result in increased toxic effects on the cerebral cortex histoarchitecture and cell morphologies of adult mice models. In view of these, we recommend further studies aimed at investigating this in humans. 


\section{REFERENCES}

1. Nehlig A, Daval JL, Debry G. 1992. "Caffeine and the central nervous system: mechanisms of action, biochemical, metabolic and psychostimulant effects". Brain Res. Brain Res. Rev. 17 (2): 139-170.

1. Bolton S. 1981. Caffeine: Psychological Effects, Use and Abuse" Orthomolecular Psychiatry 10 (3): 202-211.

2. Snel J, Lorist M.M, Tieges Z. 2004. Coffee, caffeine and cognitive performance. American Family Physician, 78 (10), 1173-1179.

3. Julien RM. 1996. A primer of Drug Action. 7th Edition. (W.H. Feeman ed.). W.H. Freeman and Co. New York. Pp. 161.

4. Obochi GO, Amali OE., Ochalefu DO 2010. Effect of Melatonin and Caffeine Interaction on Caffeine Induced Oxidative Stress and Sleep Disorders Nig. J. Physiol. Sci. 25, $17-24$.

5. Eteng, MU, Eyong EU, Akpanyong EO, Agiang MA, Aremu CY. 1997. Recent Advances in caffeine and Theobromine Toxicities: A Review. Plant food for Human Nutrition 51: $231-243$.

6. Goldman-Rakic PS. 1999.The "psychic" neuron of the cerebral cortex. Ann N Y Acad Sci.868: p. 13-26

7. Angelucci MEM, Vital MAF, Cesário C, Zadusky CR, Rosalen P, Cunha C. 1999. The effect of caffeine on animal models of learning and memory. European Journal of Pharmacology, 373: 135- 140.

8. Fatma M, Ghoneim, Hanaa A Khalaf, Ayman Z Elsamanoudy, Salwa M Abo El-khair, Ahmed MN Helaly, El-Hassanin M Mahmoud, Saad H Elshafey. 2015. Protective effect of chronic caffeine intake on gene expression of brain derived neurotrophic factor signaling and the immunoreactivity of glial fibrillary acidic protein and Ki-67 in Alzheimer's disease Int J Clin Exp Pathol ;8(7):7710-772.

9. Winston AP, Elizabeth $\mathrm{H}$, Neema J. 2005. Neuropsychiatric effects of caffeine Advances in Psychiatric Treatment, vol. 11, 432-439

10. Greden J F, Fontaine P, Lubetsky M. 1978. Anxiety and depression associated with caffeinism among psychiatric inpatients. American Journal of Psychiatry, 135, 963-966.

11. Scott N R, Chakraborty J, Marks V. 1989. Caffeine consumption in the United Kingdom: a retrospective study. Food Sciences and Nutrition, 42, 183-191.

12. Martins L J, Al-Abdulla NA, Kirsh JR, Sieber F E. 1978. Portera-Cailliau C: Neurodegeneration in excitotoxicity, global cerebral ischaemia and Target Deprivation: A perspective on the contributions of apoptosis and necrosis. Brain Res. Bull. 46(4): 281- 309.

13. Waters C M. 1994. Glutamate induced apoptosis of striatal cells in rodent model for Parkinsonism. Neuroscience 63:1-5

14. Schlosberg AJ. 1984. Acute and chronic effects of caffeine on brain monoamine levels and endocrine function in the rat. Archives of International Pharmacodynamics and Therapeutics. 267: 149-160.

15. Schuckit MA. 2000. Drug and Alcohol Abuse: A Clinical Guide to Diagnosis and treatment. (Fifth Edition). Kluwer Academic/Plenum Publishers, New York.

16. Dager SR, Layton ME, Strauss W, Richards TL, Heide A, Friedman S.D, Artru AA, Hayes CE, Posse S. 1999. Human brain metabolic response to caffeine and the effects of tolerance. American Journal of Psychiatry 156: 229-237.

17. The National Academies Press. 2011. Guide For The Care And Use of Laboratory Animals Eighth Edition, 500 Fifth Street, NW, Lockbox 285, Washington, DC 20055; http://www.nap.edu. United States of America. 